\title{
Outcome of UV-B exposure and induction of some chlorophyll phenodeviants in two important hepatoprotective ethnomedicinal wild plants
}

\author{
Kshama Dwivedi ${ }^{1,2}$ (I) $\cdot$ Kamini Kumar $^{1} \cdot$ Girjesh Kumar $^{2}$
}

Received: 30 May 2020 / Revised: 15 March 2021 / Accepted: 27 March 2021 / Published online: 15 June 2021

(c) Society for Plant Research 2021

\begin{abstract}
Present piece of work has been performed with an aim to engender genetic variations in Andrographis paniculata (Burm f.) Nees and Phyllanthus niruri L. since both plants own low or very poor genetic variations due to wild nature. A. paniculata and $P$. niruri both are magnificent hepatoprotective wild medicinal plants which have been used since ancient times as an ethnomedicine to cure several common and chronic ailments with the high competence and less side effects. UV-B radiations induce mutations because they are absorbed by major biomolecule predominantly by proteins and nucleic acids chiefly DNA. Owing to enormous potential as herbal medicines, both plants i.e. Andrographis and Phyllanthus have been selected for mutation breeding experiments using Ultraviolet-B radiations (UV-B) as a mutagen. When germinating seedlings of A. paniculata and $P$. niruri were reached up to $1-3 \mathrm{~cm}$, they were treated with UV-B radiations for $0 \mathrm{~min}, 10 \mathrm{~min}, 20 \mathrm{~min}$ and $30 \mathrm{~min}$ with a recovery period of one hour at room temperature and were planted in earthen pots in triplicates. During observations, significant variations in growth and pigment content have been observed in both plants (A. paniculata and P. niruri) in a dose based manner. A wide spectrum of chlorophyll phenodeviants (chlorophyll deficient mutants) in $\mathrm{M}_{2}$ generation such as xantha, xanthoviridis, alboviridis, virscent and chlorina mutants in A. paniculata and variegated plant, xanthoviridis, xantha and albino mutants in P. niruri have also been observed. Out of all the chlorophyll mutants obtained, few were lethal hence not survived later, while rest were survived till different stages of development. On the basis of occurrence of chlorophyll phenodeviants in Andrographis and Phyllanthus, mutagenic effectiveness and efficiency of different doses of UV-B rays have been indexed. The practice of indexing of effectiveness and efficiency of any mutagen is being used for the successful execution of mutation breeding programs to find the optimum dose that may facilitate induction of a multitude of other lucrative mutations.
\end{abstract}

Keywords A. paniculata $\cdot$ Phyllanthus niruri L. $\cdot$ Chlorophyll phenodeviants $\cdot$ Mutagenic effectiveness $\cdot$ Mutagenic efficiency $\cdot$ Hepatoprotective

\section{Introduction}

In spite of tremendous strides in modern medicine, there are hardly any drugs that stimulate liver function, offer protection to the liver from damage or help regeneration of hepatic

Kshama Dwivedi

kshama.dwivedi@gmail.com

1 Cytogenetics, Plant Breeding, Molecular Biology, and Biotechnology Laboratory, University Department of Botany, Ranchi University, Ranchi, Jharkhand 834001, India

2 Naithani Plant Genetics Laboratory, Department of Botany, University of Allahabad, Allahabad, UP 211001, India cell (Vishal 2013). However, herbal and botanical medicines formed from Andrographis paniculata (Burm f.) Nees, Phyllanthus niruri L. and other medicinal plants such as Silybum marianum, Terminalia chebula and Glycyrrhiza glabra L. (Tewari et al. 2017) have been extensively used in the traditional system of medicine for the management of liver disorder (hepatoprotection). Hence there is nothing wrong in saying 'Green Medicine' to all herbal drug-producing plants (Nearing 1985) among them two important hepatoprotective ethnomedicinal wild plants, namely Andrographis paniculata (Burm f.) Nees and Phyllanthus niruri L., have been selected for the present study.

Andrographis paniculata (Burm f.) Nees (Family-Acanthaceae) is reported as occurring wild throughout tropical 
India, and occasionally in cultivation (Sharma 2010). All aerial parts of this plant are used in traditional remedies due to astringent and anti-bacterial properties and is useful in the treatment of diabetes, influenza, bronchitis, hepatomegaly, skin disorder and many such diseases (Patra et al. 2004; Wong 2019), more specifically as hepatic stimulant and hepatoprotective agent along with other liver disorders and jaundice (Kapil et al. 1993; Tewari et al. 2017). Andrographis is also an incredible immunomodulator herb beneficial for relieving the symptoms of acute upper respiratory tract infections and could be used as immunity booster during the era of COVID-19 pandemic. Another important ethnomedicinal hepatoprotective herb taken into consideration is P. niruri L., which belongs to Euphorbiaceae family. This genus has been used since ancient times to treat a broad spectrum of diseases such as jaundice (liver disease), dysentery, dropsy, gonorrhea, menorrhagia, mild fever, stomachache, children's coughs, and more specifically the hepatitis B virus (HBV) infection, bone disorders, diabetes, intestinal infections and disturbance of the kidney and urinary bladder (Bagalkotkar et al. 2006).

Though sunlight is obligatory for photosynthesis and survival of plants, it also represents one of the major threats to their genomic integrity (Kataria 2017) due to enhanced UV-B radiation. Enhanced UV-B radiation is absorbed by a range of components within the cell, including proteins, nucleic acids, and pigments and hence could be mutagenic. Depending on the amount of UV-B absorbed, this can result in damage to proteins and DNA-resulting in delayed growth and/or cell death or induction of altered traits (Tobin 2002). Due to mutagenic properties, UV-B radiations can be applied for increasing genetic variability in several plants including economically important cereals, oilseed, ornamental and medicinal. These mutations could have been used to enhance the genetic variability via cytogenetic manipulation (chromosome can be moved, added and replaced), and could be utilized not only to increase the productivity of economically important plants but also for basic studies in various other plants; without halting the other developmental processes of treated ones (Chopra and Sharma 1985).

In general, the mutant genes of leaf color mutants or chlorophyll phenodeviants can directly or indirectly affect the pigments synthesis, degradation, content and proportion, which can block photosynthesis and lead to abnormal leaf color (Zhao et al. 2020). Leaf color mutants play an important role in the research of photosynthetic mechanisms, the chlorophyll biosynthesis pathway, chloroplast development and genetic control mechanisms (Chen et al. 2005; Tanaka and Tanaka 2006). These chlorophyll phenodeviants (chlorophyll deficient mutants) have been successfully used as genetic markers in plant breeding programs for obtaining information regarding the role and effect of different mutagens to find out the response of a particular genotype to a particular mutagen (Wani et al. 2011). Several authors have reported chlorophyll mutations in $\mathrm{M}_{2}$ generation in various crops (Wani et al. 2011; Kolar et al. 2011; Li et al. 2013; Wani 2017; Goyal et al. 2019).

The present investigation using two tremendously important hepatoprotective ethno-medicinal wild medicinal plants namely Andrographis paniculata (Burm F.) Nees., and Phyllanthus niruri L., has been undertaken with an aim to study the impact of the different time duration of UV-B irradiations in inducing phenodeviants (mutants) through mutagenesis.

\section{Material and methods}

\section{Seeds procurement}

Inbred seeds of $A$. paniculata (Kalmegh) have been procured from Birsa Agricultural University (BAU), Ranchi, and seeds of $P$. niruri L. have been provided by Dr. Anurag Mishra (MD, Ayurvedic Science).

\section{Experiment details}

For the treatment of UV-B rays, healthy and dry seeds of $A$. paniculata and $P$. niruri $\mathrm{L}$ were surface sterilized by soaking in a solution of $70 \%$ ethanol for one min and immediately rinsing three to four times with sterilized distilled water. Sterilized seeds were placed in petriplates lined with filter paper and were positioned in seed germinator (Metrex scientific instrument Pvt. Ltd. New Delhi, India) at $28 \pm 2{ }^{\circ} \mathrm{C}$ temperature and $75 \%$ relative humidity. Germinating seedlings of both $A$. paniculata and $P$. niruri L. attaining a height of $1-3 \mathrm{~cm}$ were ready for UV-B exposure. The UV-B cabinet was equipped with UV-B lamps $(\lambda=280 \mathrm{~nm}$ to $320 \mathrm{~nm}$, superior ultraviolet florescence cabinet-CX-20 equipped with internal $8 \mathrm{~W}$ tubes). Then, germinating seedlings of both the test plants were placed in UV-B cabinet and exposed to three time duration of UV-B rays i.e. $10 \mathrm{~min}$, $20 \mathrm{~min}$ and $30 \mathrm{~min}$. After treatment all the irradiated seedlings were placed in seed germinator, for recovery for at least one hour and then were planted in earthen pots in triplicates. Replicates were arranged in completely randomized block design (CRBD).

\section{Screening of chlorophyll phenodeviants}

Variations in the various kinds of chlorophyll phenodeviants of A. paniculata and P. niruri $\mathrm{L}$. were screened out in $\mathrm{M}_{2}$ generation of the UV-B irradiated growing seedlings, up to the vegetative phase. The number and types of chlorophyll phenodeviants at different time durations were recorded for further analysis. 


\section{Estimation of the mutagenic frequency, effectiveness, and efficiency}

The frequency of mutation (Mf) was calculated as a percentage of mutated $M_{2}$ plants segregated among all the $M_{2}$ plant sown while mutation effectiveness and efficiency were calculated on the basis of formula proposed by Konzak et al. (1965).

Mutagenic Effectiveness $=\frac{M f}{\text { dose }} \times 100$

Mutagenic efficiency $=\frac{M f}{I} \operatorname{or} \frac{M f}{L} \operatorname{or} \frac{M f}{S}$

Here I, $\mathrm{L}$ and $\mathrm{S}$ are the Biological damage recorded at different doses of UV-B radiation where...I = Percentage of injury or reduction in seedling germination, $\mathrm{L}=$ Percentage of lethality or reduction in survival, $\mathrm{S}=$ Percentage of pollen sterility.

\section{Estimation of Chlorophyll and Carotenoid content}

For the extraction of pigments content ( $\mu \mathrm{g} / \mathrm{mg} \mathrm{FW})$, Lichtenthaler and Wellburn, 1983 method was adopted and the absorption spectrum of different pigments was recorded at wavelength corresponding to $663 \mathrm{~nm}, 646 \mathrm{~nm}$ and $470 \mathrm{~nm}$, respectively, using Eppendorf BioSpectrometer ${ }^{\circledR}$ kinetic (Germany).

\section{Results}

The present piece of work encompasses observations in $\mathrm{M}_{2}$ generation of UV-B rays $(280-320 \mathrm{~nm})$ mutagenized two hepatoprotective wild medicinal plants which has been categorised in the following subheads-

\section{Effect on growth characters (germination and survival percentage)}

The preliminary impact of UV-B rays has been observed in terms of variation in germination and survival percentage (Table 1). Studies on the UV-B exposed seedlings of $\mathrm{M}_{2}$ generation of $A$. paniculata (Kalmegh) shows maximum germination percentage at 20 min duration of UV-B treatment and recorded to be as $95.54 \pm 0.69 \%$ which was more than that of control $(93.89 \pm 0.47 \%)$ while minimum germination \% was noticed as $88.27 \pm 2.64 \%$ at 30 min duration. Maximum survival percentage in kalmegh was found insignificant at $10 \mathrm{~min}$ duration. However, in P. niruri L., $10 \mathrm{~min}$ of UV-B exposure time shows maximum germination percentage $(97.44 \pm 0.49 \%)$ and maximum survival percentage in control and recorded to be $94.81 \pm 0.23 \%$.

\section{Effects on photosynthetic pigments}

Data analysis revealed the significant impact of UV-B radiations on chlorophyll a, chlorophyll b, and carotenoid content.

Chlorophyll a $\left(\frac{\mathrm{ug}}{\mathrm{mg}} \mathrm{FW}\right)=\frac{12.25\left(A_{663}\right)-2.79\left(A_{646}\right) \times \text { volume }(\mathrm{ml})}{\text { weight of leaf tissue }(\mathrm{mg})}$

Chlorophyll b $\left(\frac{\mathrm{ug}}{\mathrm{mg}} \mathrm{FW}\right)=\frac{21.5\left(A_{646}\right)-5.1\left(A_{663}\right) \times \text { volume }(\mathrm{ml})}{\text { weight of leaf tissue }(\mathrm{mg})}$

Carotenoids $\left(\frac{\mathrm{ug}}{\mathrm{mg}} \mathrm{FW}\right)=\frac{\left[1000\left(A_{470}\right)-1.82(\text { Chl a })-85.02(\mathrm{Chl} \mathrm{b})\right] / 198 \times \text { volume }(\mathrm{ml})}{\text { weight of leaf tissue }(\mathrm{mg})}$

\section{Statistical analysis of the data}

All the experiments were conducted in three replicates and were repeated thrice to confirm the reproducibility of the results. Mean of the morphological variables were subjected to one-way variance analysis (ANOVA) using Duncan's multiple range test (DMRT) at $(p<0.05)$ to study the significance of the data. All the statistical analyses and graphical representations have been done using SPSS 16.0 and Sigma Plot 10 , respectively.
Chlorophyll a. In A. paniculata significant increase in chlorophyll a content was recorded at 20min duration of radiation while, rest two doses showed a dose based reduction in their values as compared to control. In Phyllanthus 20min duration followed by $10 \mathrm{~min}$ duration L. possessed higher chlorophyll content over control. A $30 \mathrm{~min}$ exposure time of UV-B rays curtailed down the amount of chlorophyll $\mathrm{a}$ in both plants significantly (Graph 1 and 2).

Chlorophyll b: All the doses of treated sets possessed an increment in chlorophyll b content in A. paniculata as 
Table 1 Effect of UV-B rays on germination and survival percentage of Andrographis paniculata (Kalmegh) and Phyllanthus niruri L. in $\mathrm{M}_{2}$ generation

\begin{tabular}{|c|c|c|c|c|}
\hline \multirow{2}{*}{$\begin{array}{l}\text { Treatment (germina- } \\
\text { tion \%) }\end{array}$} & \multicolumn{2}{|l|}{ Germination (\%) } & \multicolumn{2}{|l|}{ Survival (\%) } \\
\hline & $\begin{array}{l}\text { A. paniculata (Kalmegh) } \\
(\text { mean } \pm \mathrm{SE})\end{array}$ & P. niruri L. (mean $\pm \mathrm{SE})$ & $\begin{array}{l}\text { A. paniculata (Kalmegh) } \\
(\text { mean } \pm \text { SE) }\end{array}$ & P. niruri L. (mean $\pm \mathrm{SE})$ \\
\hline Control & $93.89 \pm 0.47^{c^{*}}$ & $96.54 \pm .40^{\mathrm{a}^{*}}$ & $91.19 \pm 0.96^{\mathrm{a}^{*}}$ & $94.81 \pm 0.23^{\mathrm{ab}^{*}}$ \\
\hline $10 \mathrm{~min}$ & $92.75 \pm .55^{\mathrm{bc}}$ & $97.44 \pm 0.49^{\mathrm{a}}$ & $90.43 \pm 0.42^{\mathrm{a}}$ & $94.23 \pm 0.10^{\mathrm{ab}}$ \\
\hline $20 \mathrm{~min}$ & $95.54 \pm .69^{\mathrm{a}}$ & $96.05 \pm 0.33^{\mathrm{a}}$ & $85.43 \pm .057^{\mathrm{b}}$ & $89.52 \pm 0.35^{c}$ \\
\hline $30 \mathrm{~min}$ & $88.27 \pm 2.64^{\mathrm{d}}$ & $92.44 \pm .84^{\mathrm{c}}$ & $75.48 \pm .061^{\mathrm{c}}$ & $81.98 \pm 0.98^{\mathrm{d}}$ \\
\hline
\end{tabular}

*(Mean $\pm \mathrm{SE})(\mathrm{p}<0.05)$ by Duncan's Multiple Range Test $(\mathrm{DMRT})$ One way ANOVA

compared to control (Graph 1) and maximum accessory pigment content was recorded at 20 min duration of UV-B rays treatment. In $P$. niruri $L$. significant reduction in the chlorophyll $\mathrm{b}$ content was recorded at $30 \mathrm{~min}$ exposure of UV-B rays.

Carotenoid: In Andrographis 20min. duration had higher content of carotenoid while in Phyllanthus none of the doses showed increment over control. The lowest content of the pigment was recorded at $30 \mathrm{~min}$ duration in kalmegh. A different trend of significant reduction and increment in carotenoid content was observed at 20min duration of UV-B treatment in $P$. niruri $L$. and $A$. paniculata, respectively as compared to control.

\section{Induced chlorophyll phenodeviants procured in $\mathbf{M}_{\mathbf{2}}$ generation}

The phenotypic selection for mutant was not done in the $\mathrm{M}_{1}$ generation since the first mutation population $\left(\mathrm{M}_{1}\right)$ suffers from physiological disorders as a result of the mutagen treatment. Since the mutations are mostly recessive hence mutant phenotype usually expresses itself in $\mathbf{M}_{2}$ generation when the progeny is in homozygous condition (Shu et al. 2011).

Photosynthetic pigments are the first target of UV-B rays and induced several chlorophyll mutants in $\mathbf{M}_{2}$ generation. Thus various types of chlorophyll phenodeviants (chlorophyll deficient mutants) such as xantha, xanthoviridis, alboviridis, virscent and chlorina mutants in A. paniculata and variegated plant, xanthoviridis, xantha and albino mutants in $P$. niruri have been screened out and few of them were lethal.

Plenty of chlorophyll phenodeviants have been recovered in $\mathrm{M}_{2}$ generation of both test plants viz.-Albina mutantsphenotypically having the white leaves being smaller and narrow (Fig. 1j), Chlorina mutants-Yellowish green in colour sometimes unable to survive till maturity (Fig. 1g, k). Virescent mutants - light or yellowish green in early stage become darker green in later stage of development (Fig. 1b, e), Viridis mutants - these mutants are heterogeneous with regard to the intensity of the green colour (Fig. 1f, i). Many viridis mutations reach maturity and produce, Xantha
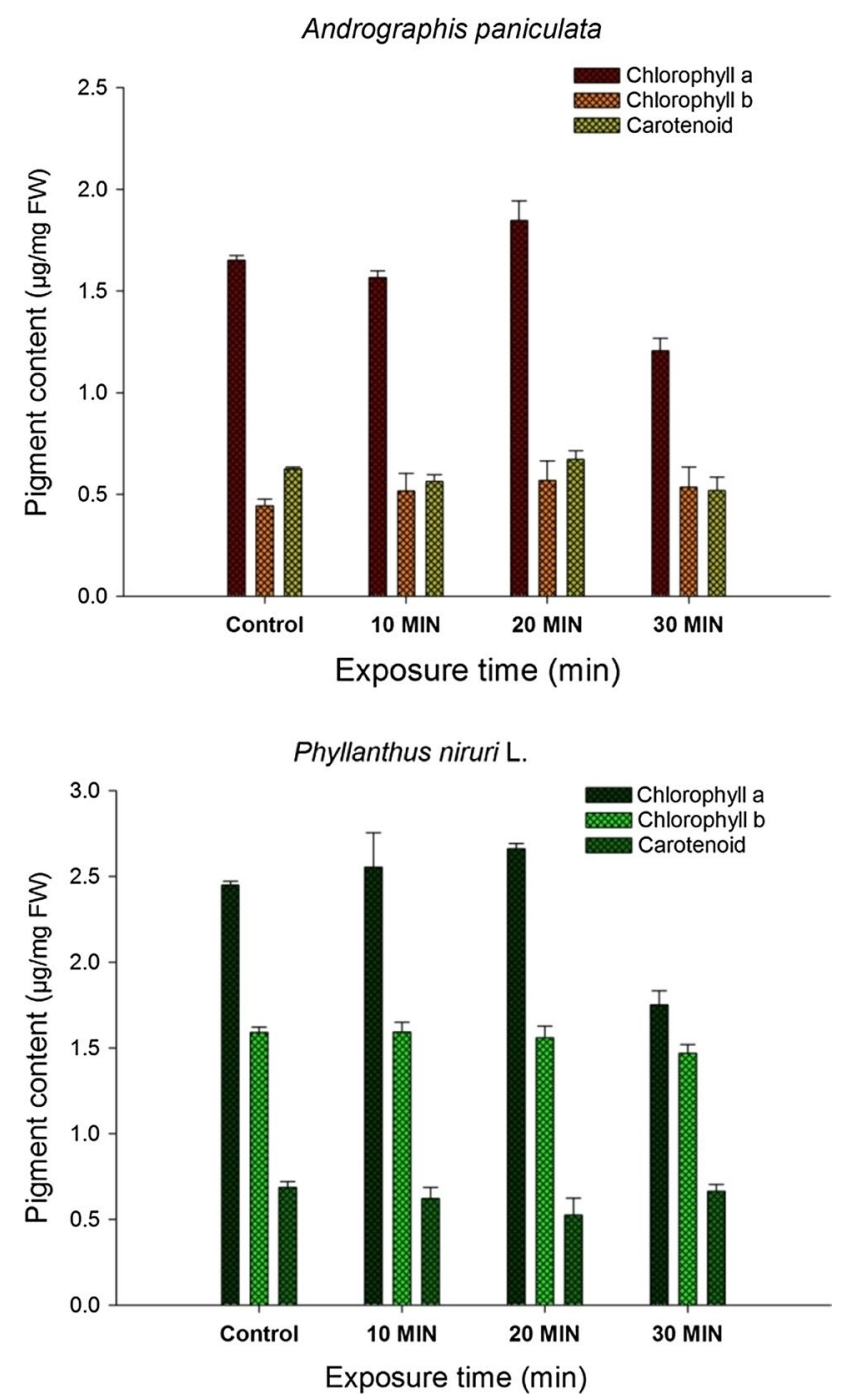

Graph 1 and 2 Effects of UV-B rays exposures on pigments content of A. paniculata and P. niruri L. in M2 generation

mutants - seedlings in these mutants match yellow colours exactly (Fig. 1c). 
Fig. 1 a-l Chlorophyll phenodeviants of $A$. paniculata, a normal young plant, $\mathbf{b}$ virescent true leaf and cotyledonory leaves, c xantha true leaf with normal cotyledonory leaves, d alboviridis (yellow arrow head) and xanthoviridis (red arrow), e virescent second (red arrow) and further true leaf with normal first green leaf (yellow arrow head), $\mathbf{f}$ viridis true leaves (one heart shaped), $\mathbf{g}$ bifurcated leave with chlorina mutant, Chlorophyll phenodeviants of $\boldsymbol{P}$. niruri $\mathrm{L}$. (h-l), h normal green plant, $\mathbf{i}$ viridis mutant plant (with leaf architecture variation), $\mathbf{j}$ albina mutant, $\mathbf{k}$ chlorina mutant, $\mathbf{I}$ variegated plant, Pollen grains $(\mathbf{m}, \mathbf{n}), \mathbf{m}$ fertile and sterile pollen grains of $A$. paniculata, $\mathrm{n}$ a sterile pollen grain of Phyllanthus niruri $L$.
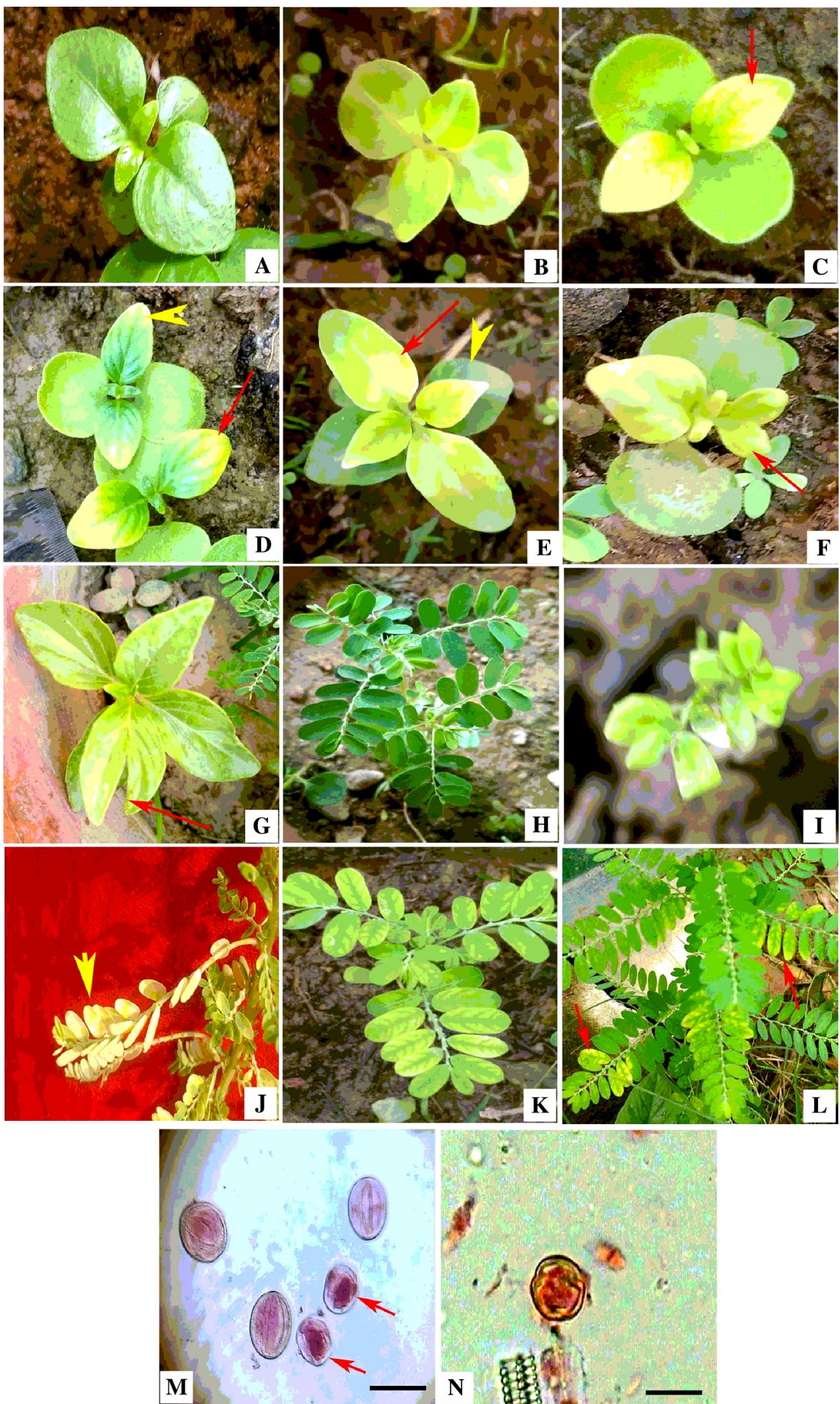
Some other mixed chlorophyll mutants were also identified as variegated (Fig. 11), xanthoviridis and alboviridis mutations (Fig. 1d). Chlorophyll mutations has been categorized by following classification proposed by Gustafson 1942 with some modification by Goyal et al. (2019).

\section{Mutagenic effectiveness and efficiency}

Computation of the frequency of chlorophyll mutants was done for estimation of the mutagenic effectiveness and efficiency as indexed in Tables 2 and 3, respectively; which varies from plant to plant and for various doses of mutagens. In A. paniculata and P. niruri, trend of mutagenic effectiveness was recorded to be the same (Table 2) and found to be the highest at 10 min UV-B treatment but the number of mutants scored was higher in A. paniculata. Another significant phenomenon is mutagenic efficiency [calculated as the frequency of mutation in terms of biological damage viz. injury (I), lethality (L) and sterility (S)] of the mutagen onto the mutagenized plant populations. Mutagenic efficiency calculated in terms of biological damage indicated that sterility was higher at 10 min treatment and the seedling injury was significantly higher at 20 min duration in Andrographis. Overall mutagenic efficiency was similar to that of mutagenic effectiveness in kalmegh as presented in Table 3. However, in Phyllanthus seedling injury was significantly higher at the lowest exposure time of UV-B rays as compared to the other two parameters of biological damage.

\section{Discussions}

Majority of plants are exposed to enhanced levels of UV-B radiation (Hollósy 2002). UV-B radiations have potential to mutate several important biomolecules of plant cells particularly nuclear DNA, protein, and lipids (Kovács and Keresztes 2002; Gill et al. 2015). This is the reason why UV-radiations have been used as a mutagenic agent during mutagenesis of
Table 2 Mutagenic effectiveness of UV-B rays in inducing chlorophyll phenodeviants (mutants) in $A$. paniculata (kalmegh) and $P$. niruri $L$. in $\mathrm{M}_{2}$ generation

\begin{tabular}{lllll}
\hline Treatment & $\begin{array}{l}\text { Total no. of plants raised } \\
\text { in } \mathrm{M}_{2} \text { generation }\end{array}$ & $\begin{array}{l}\text { No of mutated } \\
\text { plant }\end{array}$ & $\begin{array}{l}\text { Mutation frequency } \\
\text { (Mf) }(\%)\end{array}$ & $\begin{array}{l}\text { Mutagenic effec- } \\
\text { tiveness (=Mf/ } \\
\text { dose) }\end{array}$ \\
\hline $\begin{array}{l}\text { A. paniculata } \\
\text { Control }\end{array}$ & 30 & & & \\
10 min & 30 & 0 & 0.00 & 0.00 \\
20 min & 30 & 3 & 10.00 & 1.00 \\
30 min & 30 & 2 & 6.66 & 0.22 \\
P. niruri L. & & 0 & 0.00 & 0.00 \\
Control & 30 & & & \\
10 min & 30 & 0 & 0 & 0.00 \\
20 min & 30 & 2 & 6.66 & 0.66 \\
30 min & 30 & 1 & 3.33 & 0.16 \\
\hline
\end{tabular}

Table 3 Mutagenic efficiency of UV-B rays in inducing chlorophyll mutants in A. paniculata (Kalmegh) and P. niruri in $\mathrm{M}_{2}$ generation

\begin{tabular}{|c|c|c|c|c|c|c|}
\hline Treatment & Injury $(\mathrm{I})^{\mathrm{a}}(\%)$ & $\begin{array}{l}\text { Mutation effi- } \\
\text { ciency (=Mf/I) }\end{array}$ & Lethality (L) $)^{\mathrm{a}}(\%)$ & $\begin{array}{l}\text { Mutation efficiency } \\
(=\mathrm{Mf} / \mathrm{L})\end{array}$ & Sterility $(\mathrm{S})^{\mathrm{a}}(\%)$ & $\begin{array}{l}\text { Mutation } \\
\text { efficiency } \\
(=\mathrm{Mf} / \mathrm{S})\end{array}$ \\
\hline \multicolumn{7}{|c|}{ A. paniculata (Kalmegh) } \\
\hline Control & 2.11 & 0.00 & 8.81 & 0.00 & 0.37 & 0.00 \\
\hline $10 \mathrm{~min}$ & 8.11 & 1.23 & 9.57 & 1.04 & 4.82 & 2.07 \\
\hline $20 \mathrm{~min}$ & 4.46 & 1.49 & 14.57 & 0.46 & 12.50 & 0.53 \\
\hline $30 \mathrm{~min}$ & 11.73 & 0.00 & 24.52 & 0.00 & 20.75 & 0.00 \\
\hline \multicolumn{7}{|c|}{ Phyllanthus niruri L. } \\
\hline Control & 3.46 & 0.00 & 5.19 & 0.00 & 0.93 & 0.00 \\
\hline $10 \mathrm{~min}$ & 2.56 & 2.60 & 5.77 & 1.15 & 2.71 & 2.45 \\
\hline $20 \mathrm{~min}$ & 3.59 & 0.92 & 10.48 & 0.31 & 7.59 & 0.43 \\
\hline $30 \mathrm{~min}$ & 7.56 & 0.00 & 18.02 & 0.00 & 14.68 & 0.00 \\
\hline
\end{tabular}

${ }^{a}$ Biological damage: Injury $(\mathrm{I})=$ reduction in seedling germination, Lethality $(\mathrm{L})=$ reduction in plant survival, Sterility $(\mathrm{S})=$ reduction in pollen fertility 
Andrographis paniculata and Phyllanthus niruri. Since both plants possess very low and poor genetic variability hence there is an urgent need for creation of genetic variability for better survival of both immensely therapeutic wild plants. It could be made possible by mutagenesis since mutations are an indispensable vehicle of diversity in populations via introduction of new allele.

Seedlings with slender stem are suitable material because of small penetrating power of non-ionizing UV-B rays (Fujii 1965). From the seeds of $M 1, M_{2}$ - generation was raised and studied in details for mutant screening and selection.

Germination is an important parameter used to measure the response of the plant to mutagenic treatments (Shah et al. 2008). In the present study, delayed germination in $M_{2}$ generation was found at higher doses of UV-B radiation. It might be due to chromosomal aberrations/delay in DNA synthesis/delayed metabolic process. On the other hand higher germination was recorded at optimal doses which is in conformity with Dwivedi (2014); who reported the high germination percentage in Brassica campestris seedling irradiated at a lower dose of UV-B irradiation. Nonetheless despite possessing high germination percentage at $20 \mathrm{~min}$ and 10 min UV-B treatment in A. paniculata and P. niruri, the reduction in their survival percentage might be due to induced lethal chlorophyll mutations which were unable to survive after a certain period of time.

Chlorophyll a is a vital biomolecule that plays a critical role in photosynthesis by absorbing light and transferring light energy to the reaction centers of the photosynthetic system (Li et al. 2013). In the present study, at 20 min treatment set, we have recorded the higher chlorophyll $b$ content in the treated plants of Andrographis as compared to control. It has also been mentioned in the literature that UV-B radiation resulted in the reduction of the amount of chlorophyll a as opposed to chlorophyll $b$ and might point as more selective destruction of chlorophyll a biosynthesis or degradation of precursors (Marwood and Greenberg 1996). Furthermore a rise in chlorophyll $\mathrm{b}$ content could be explained as this accessory pigment is more adaptive to stress condition and also act as a protector molecule for reaction centre.

On the other hand treatment with less time duration of UV-B radiation in both the plants showed an increase in chlorophyll content which is in tune with Mensah et al. (2007). Our observation is also in line with the finding of Kumar and Pandey (2017), who suggested that chlorophylls and carotenoids are affected by differential UV-B radiation doses.

It is obvious that chlorophyll is essential for plant development and agricultural production (Eckhardt et al. 2004; Flood et al. 2011). Here in the present study UV-B rays induced a range of chlorophyll phenodeviants such as xantha, xanthoviridis, alboviridis, virscent and chlorina mutants in A. paniculata and variegated plant, xanthoviridis, xantha and albino mutants in P. niruri. The chlorophyll deficiency throughout development inhibited photosynthesis and consequently affected the accumulation of biomass and the proper development of the plant ( $\mathrm{Li}$ et al. 2013). Among all the induced chlorophyll phenodeviants reported here, few of them such as albina and xantha (owing to complete absence of chlorophyll) were lethal thus unable to survive till maturity, this might be due to the homozygous recessive mutation in $\mathrm{M}_{2}$ progeny. Several workers also reported a higher frequency of these kinds of chlorophyll phenodeviants in irradiated population, (Cheema and Atta 2003; Subramanian et al. 2011 in kodo millet, Kolar et al. 2011 in Delphinium malabaricum). Higher frequency of chlorophyll mutations with medium or lower doses of mutagen were reported by Nadarajan et al. (1982) in Cajanus cajan, while other reports indicated a dose-dependent increase in chlorophyll mutation frequency (Barshile et al. 2006). These chlorophyll mutants if survived have a significant horticultural significance since it gives the plant an ornamental look particularly in A. paniculata hence could be grown as garden hedges.

Mutagenic effectiveness is an indicator of the genotypic sensitivity towards the increasing mutagenic dose, while mutagenic efficiency explains the proportion of mutations in relation to the undesirable biological effects, such as, seedling injury, lethality, and pollen sterility induced by the particular mutagen (Laskar and Khan 2017). In both the test plants (A. paniculata and P. niruri), the trend of mutagenic effectiveness was recorded to be the same and found to be highest at a lower treatment dose of UV-B rays. Similar observations of a general decrease in effectiveness with increasing doses of radiation were reported in, foxtail millet by Gupta and Yashvir (1975), in, mungbean by Solanki and Sharma (1994) and in, finger millet by Ambavane et al. (2015). Mutagenic frequency is directly correlated with mutagenic effectiveness and inversely associated with the treatment doses. As mentioned in the results that seedling injury was significantly higher at 20 min duration in kalmegh. The occurrence of lethal chlorophyll phenodeviants might be the cause of seedling injury at this particular dose. In the mutation breeding program, a high mutation rate accompanied by minimal deleterious effects is described (Ramchander et al. 2014). But generally the mutagen that gives the higher mutation rate also induces a high degree of lethality, sterility, and other undesirable effects (Blixt 1961).

\section{Conclusions}

Based on present study, it can be concluded that in both the test plants, UV-B rays can be used to induce various chlorophyll phenodeviants that can survive till maturity except some lethal mutants. Furthermore, on the basis of lived chlorophyll phenodeviants, mutagenic effectiveness 
and efficiency can be calculated in both plants (Andrographis Phyllanthus niruri), suggesting that less exposure time duration of UV-B irradiation is beneficial. It could further be used to create some more chlorophyll phenodeviants (mutants) which can provide a high value ornamental glimpse for horticulture purpose. In addition, chlorophyll mutations are important for identifying gene function and elucidation of chlorophyll metabolism and its regulation (Wu et al. 2007). Further biochemical studies reveal that 20 min duration of UV-B treatment in Andrographis increases pigment content even more than control suggesting the stimulatory response of this dose.

On another aspect, induced mutants via UV-B irradiations may generate some novel variations (for example, better germination and survival mutant, high yielding and induced chlorophyll phenodeviants etc.) which can be better suited to the contemporary indefinite period of climate change. On the other hand, in the present times several contagious diseases are slowly spread its footing (like COVID pandemic) which can be avoided by the use of herbal drug having immuneboosting and hepatoprotective properties.

Acknowledgements Thanks are due to 'Naithani plant genetics laboratory' University of Allahabad and 'Cytogenetics, plant breeding, molecular biology, and biotechnology laboratory' Ranchi University, for providing necessary facilities and to the lab members for supporting us during work. Thanks are also due to Dr. Jai Kumar, BAU Ranchi for providing seeds of Kalmegh. One of the authors Dr. Kshama Dwivedi is highly grateful to CSIR, New Delhi for providing financial assistance as CSIR-Research Associate (RA).

\section{References}

Ambavane AR, Sawardekar SV, Sawantdesai SA, Gokhale NB (2015) Studies on mutagenic effectiveness and efficiency of gamma rays and its effect on quantitative traits in finger millet (Eleusine coracana L. Gaertn). J Radiat Res Appl Sci 8:120-125

Bagalkotkar G, Sagineedu SR, Saad MS, Stanslas J (2006) Phytochemicals from Phyllanthusniruri Linn. and their pharmacological properties: a review. J Pharm Pharmacol 58(12):1559-1570. https:// doi.org/10.1211/jpp.58.12.0001

Barshile JD, Auti SG, Dalve SC, Apparao BJ (2006) Mutagenic sensitivity studies in chickpea employing SA, EMS and gamma rays. Indian J Pulses Res 19(1):43-46

Blixt S (1961) Quantitative studies of induced mutation In peas, V, Chlorophyll mutations. Agric Hort Genet 19:402-447

Cheema AA, Atta BM (2003) Radiosensitivity studies in basmati rice. Pak J Bot 35(2):197-207

Chen G, Bi YR, Li N (2005) EGY1 encodes a membrane-associated and ATP-independent metalloprotease that is required for chloroplast development. Plant J 41:364-375

Chopra VL, Sharma RP (1985) Induced mutations in crop improvement. Genetic manipulation for crop improvement. Oxford and IBH publishing Co., New Delhi, pp 23-48

Dwivedi K (2014) Isolation of yield contributing mutant lines in Brassica campestris L. Thesis, University of Allahabad, pp 70-76
Eckhardt U, Grimm B, Hortensteiner S (2004) Recent advances in chlorophyll biosynthesis and breakdown in higher plants. Plant Mol Biol 56:1-14

Flood PJ, Harbinson J, Aarts MG (2011) Natural genetic variation in plant photosynthesis. Trends Plant Sci 16:327-335

Fujii T (1965) Effects of UV-rays on Arabidopsis seedlings. In: Röbbelen G (ed) Arabidopsis research, report of the international symposium, Gottingen. University of Göttingen, Göttingen, pp 147-151

Gill SS, Anjum NA, Gill R, Jha M, Tuteja N (2015) DNA damage and repair in plants under ultraviolet and ionizing radiations. Sci World J 2015:1-11

Goyal S, Wani MR, Khan S (2019) Frequency and spectrum of chlorophyll mutations induced by single and combination treatments of gamma rays and EMS in urdbean. Asian J Biol Sci 12(2):156-163

Gupta PK, Yashvir P (1975) Induced mutations in foxtail millet (Setariaitalica Beauv.): I Chlorophyll mutations induced by gamma rays, EMS and DES. Theor Appl Genet 45(6):242-249

Gustafsson A (1942) The plastid development in various types of chlorophyll mutations. Hereditas 28(3-4):483-492

Hollósy F (2002) Effects of ultraviolet radiation on plant cells. Micron 33(2):179-197

Kapil A, Koul IB, Banerjee SK, Gupta BD (1993) Antihepatotoxic effects of major diterpenoid constituents of Andrographis paniculata. Biochem Pharmacol 46:182-185. https://doi.org/10.1016/ 0006-2952(93)90364-3

Kataria S (2017) UV-B radiation: from environmental stressor to regulator of plant growth, book chaptor (oxidative stress and antioxidative defence system in plants in response to UV-B stress). Wiley, Chichester, p 110

Kolar F, Pawar N, Dixit G (2011) Induced chlorophyll mutations in Delphinium malabaricum (Huth) Munz. J Appl Hortic 13(1):18-24

Konzak CP, Wagner RA, Nilan J, Foster RJ (1965) Efficient chemical mutagenesis. Radiat Bot 5(Suppl):49-70

Kovács E, Kereszte Á (2002) Effect of gamma and UV-B/C radiation on plant cells. Micron 33(2):199-210

Kumar G, Pandey A (2017) Effect of UV-B radiation on chromosomal organisation and biochemical constituents of Coriandrum sativum L. Jordan J Biol Sci 10(2):85-93

Laskar RA, Khan S (2017) Mutagenic effectiveness and efficiency of gamma rays and $\mathrm{HZ}$ with phenotyping of induced mutations in lentil cultivars. Int Lett Nat Sci 64:17-31

Li N, Jizeng J, Chuan X, Xu L, Xiuying K (2013) Characterization and mapping of chlorophyll mutant genes in wheat. Breed Sci 63:169-175

Lichtenthaler HK, Wellburn AR (1983) Determinations of total carotenoids and chlorophylls a and b of leaf extracts in different solvents. Biochem Soc Trans 11:591-592

Marwood CA, Greenberg BM (1996) Effect of supplementary UV-B radiation on chlorophyll synthesis and accumulation of photosystems during chloroplast development in Spirodela oligorrhiza. Photochem Photobiol 64(4):664-670

Mensah JK, Obadoni BO, Akomeah PA, Ikhajiagbe B, Ajibolu J (2007) The effects of sodium azide and colchicine treatments on morphological and yield traits of sesame seed (Sesameindicum L.). Afr J Biotechnol 6(5):534-538

Nadarajan W, Sathupati R, Shivaswamy N (1982) Investigation on induced macromutations in Cajanus cajan. Madras Agricultural Journal 69:713-771

Nearing M (1985) The green pharmacy Herbal medicines in modern usage. IDRC Rep 14(1):10-11

Patra DD, Chattopadhyay A, Singh AK, Tomar VKS, Singh A, Mishra HO, Alam M, Khanuja SPS (2004) Agro technology of 
Kalmegh (Andrographis paniculata). J Med And Aromat Plant Sci 26:475-478

Ramchander S, Pillai MA, Ushakumari R (2014) Effectiveness and efficiency of physical and chemical mutagens inducing chlorophyll mutants in two rice genotypes. Madras Agric J 101(7-9):212-218

Shah TM et al (2008) Induced genetic variability in chickpea (Cicerarietinum L.) II. Comparative mutagenic effectiveness and efficiency of physical and chemical mutagens. Pak J Bot 40(2):605-613

Sharma S (2010) Growth, productivity and quality of kalmegh [Andrographis paniculata (burm f.) wall ex nees] as affected by levels of nitrogen and phosphorus. Krishikosh Institutional Repository, pp 1-114

Shu QY, Forster BP, Nakagawa H (2011) Plant mutation breeding and biotechnology: plant breeding and genetics section. Joint FAO/ IAEA Division of Nuclear Techniques in Food and Agriculture International Atomic Energy Agency, Vienna, Austria, Joint FAO/ IAEA programme

Solanki IS, Sharma B (1994) Mutagenic effectiveness and efficiency of gamma rays, ethyleneimine and $\mathrm{N}$-nitroso-Nethyl urea in macrosperma lentil (Lensculinaris Medik.). Indian J Genet Plant Breed 54(1):72-76

Subramanian A, Nirmalakumari A, Veerabadhiran P (2011) Mutagenic efficiency and effectiveness in kodo millet (Paspalumscrobiculatum L.). Madras Agric J 98(1-3):22-25

Tanaka A, Tanaka R (2006) Chlorophyll metabolism. Curr Opin Plant Biol 9:248-255

Tewari D, Mocan A, Parvanov ED, Sah AN, Nabavi SM, Huminiecki L, Ma ZF, Lee YY, Horbańczuk JO, Atanasov AG (2017) Ethnopharmacological approaches for therapy of jaundice: Part II. Highly used plant species from Acanthaceae, Euphorbiaceae, Asteraceae, Combretaceae, and Fabaceae families. Front Pharm 8(521):1-14

Tobin AK (2002) The effects of ultraviolet $b$ radiation on crop plants. In: Ambasht RS, Ambasht NK (eds) Modern trends in applied terrestrial ecology. Springer, Boston

Vishal R (2013) Protective role of Indian medicinal plants against liver damage. J Phytopharmacol 2(3):1-3

Wani MR (2017) Induced chlorophyll mutations, comparative mutagenic effectiveness and efficiency of chemical mutagens in lentils (Lens culinaris Medik.). Asian J Plant Sci 16(4):221-226

Wani MR, Khan S, Kozgar MI (2011) Induced chlorophyll mutations. I. Mutagenic effectiveness and efficiency of EMS, HZ and SA in mungbean. Front Agric China 5(4):514-518

Wong C (2019) The Health Benefits of Andrographis Medically reviewed by Richard N. Fogoros, MD, https://www.verywellhe alth.com/can-andrographis-boost-immune-function- 89538 . Accessed 24 May 2020

Wu ZM, Zhang X, He B, Diao LP, Sheng SL, Wang JL, Guo XP, Su N, Wang LF, Jiang L et al (2007) A chlorophyll-deficient rice mutant with impaired chlorophyllide esterification in chlorophyll biosynthesis. Plant Physiol 145:29-40

Zhao MH, Li X, Zhang XX, Zhang H, Zhao XY (2020) Mutation mechanism of leaf color in plants: a review. Forests 11:851

Publisher's Note Springer Nature remains neutral with regard to jurisdictional claims in published maps and institutional affiliations. 